\title{
Importance of Neutrophil-Lymphocyte Ratio in the Management of Children with Cervical Lymphadenopathy
}

\section{Servikal Lenfadenopatili Çocuklarmn Yönetiminde Nötrofil-Lenfosit Oranının Önemi}

\author{
$\underline{\text { Selin Üstün Bezgin }}{ }^{1}$, Taliye Çakabay ${ }^{1}$, Işık Odaman $\mathrm{Al}^{2}$, Ali Aycicek², Ferhan $\mathrm{Akıc1}^{2}$, Havva Duru İpek ${ }^{1}$ \\ ${ }^{1}$ İstanbul Kanuni Sultan Süleyman Eğitim ve Araştırma Hastanesi, Otorinolaringoloji Departmanı, İstanbul, \\ Türkiye \\ ${ }^{2}$ İstanbul Kanuni Sultan Süleyman Eğitim ve Araştırma Hastanesi, Çocuk Hematoloji ve Onkoloji Departmanı, \\ İstanbul, Türkiye
}

Dergiye Ulaşma Tarihi: 15.09.2019 Dergiye Kabul Tarihi:04.12.2019 Doi: 10.5505/aot.2019.82542

\begin{abstract}
ÖZET
GÍRIŞ ve AMAÇ: Servikal lenfadenopati, pediatrik hastalarda sık görülen bir semptomdur. Ek prediktif faktörlerin arttırılması, malign nedenleri iyi huylu nedenlerden ayırmak için kritik öneme sahiptir. Bu çalışmada, servikal lenfadenopatili çocukların değerlendirilmesinde nötrofil lenfosit oranının klinik önemini değerlendirmeyi amaçladık.

YÖNTEM ve GEREÇLER: Çalışmaya 18 yaş altı 86 çocuk hasta dahil edildi. Üç grup oluşturuldu ve kontrol grubu olan grup 1 (30 çocuk) hastanemizde sünnet veya inguinal herni nedeniyle opere edilen hastalardan oluşmaktadır. Grup 2 çalş̧ma grubu (30 çocuk) olup kulak burun boğaz ve/veya pediatric hematoloji-onkoloji polikliniklerinde kronik servikal lenfadenopati nedeniyle değerlendirilen hastalardan olușmaktadır. Grup 3 (26 çocuk) ise Hodgkin lenfoma tanılı hastalardan oluşmaktadır. Tüm grupların nötrofil-lenfosit oranları analiz edilmiştir.
\end{abstract}

BULGULAR: Ortalama nötrofil-lenfosit oranları açısından grup 1 ve grup $3(\mathrm{p}<0.05)$ ile grup 2 ve grup3 (p $<0.05$ ) arasında anlamlı farklılık saptanmıșken grup1 ve grup 2 arasında anlamlı farklılık saptanmamıștır (p $>0.05$ ). ROC eğrisinde maksimum kombine hassasiyete ve özgüllüğe karşıllk gelen 1.2 nötrofil-lenfosit oranı değerine dayanarak bir alıcı ROC analizi yapıldı ve $\% 40$ hassasiyet ve $\% 33$ özgüllük belirlendi.

TARTIŞMA ve SONUÇ: Bu çalışmada lenfomalı grupta diğer gruplara göre yüksek nötrofil-lenfosit oranları ortaya koymaktadır. Ancak düşük özgüllük ve hassasiyet değerleri, maligniteyi tespit etmek için parametrenin güvenilir olarak kullanımını kısıtlar.

Anahtar Kelimeler: Çocuk, lenfadenopati, nötrofil, lenfosit

\begin{abstract}
INTRODUCTION: Cervical lymphadenopathy is a common presenting symptom in pediatric patients. The differentiation of malignant from benign causes and increasing the armamentarium of additional predictive factors is critically important. In this study, we aimed to assess the clinical importance of neutrophil-lymphocyte ratio in the evaluation of children with cervical lymphadenopathy.

METHODS: Eighty-six (n: 86) children ( $<18$ years of age) were the subjects of this study. Three groups were assigned and group 1 as a control patients (n: 30) who underwent circumcision or inguinal hernia repair in our hospital. Group $2(\mathrm{n}=30)$ as a study group composed of patients who were examined in the otorhinolaryngology and/or pediatric hematology-oncology outpatient clinics due to chronic enlarged cervical lymph nodes. Group 3 $(n=26)$ was composed of patients who were diagnosed with Hodgkin lymphoma. The neutrophil-lymphocyte ratio in the groups were analyzed.

RESULTS: There was significant differences between the mean neutrophil-lymphocyte ratios of group 1 and 3 ( $\mathrm{p}<0.05$ ) and group 2 and $3(\mathrm{p}<0.05)$ whereas no significant difference was found between group 1 and $2(\mathrm{p}$ $>0.05$ ). A receiver operating characteristic (ROC) curve analysis was performed based on the neutrophillymphocyte ratio value of 1.2 corresponded to the maximum combined sensitivity and specificity on the ROC curve and $40 \%$ sensitivity and $33 \%$ specificity were determined.

DISCUSSION and CONCLUSION: Present study reveals higher neutrophil-lymphocyte ratio in lymphoma group than the others. However low specificity and sensitivity values restricts the use of a reliable parameter to detect malignancy.
\end{abstract}


Keywords: Child, lymphadenopathy, neutrophils, lymphocytes

\section{INTRODUCTION}

Lymphadenopathy (LAP) is defined as an abnormality in the size or character of the lymph node (1), and can be caused by infectious, autoimmune, chronic inflammatory or malignant disease $(1,2)$. Cervical lymphadenopathy is a common presenting symptom in pediatric patients and is a frequently encountered examination finding among pediatricians and otorhinolaryngologists (3), with distribution and size being important characteristics in the clinical evaluation of abnormally enlarged lymph nodes $(1,3)$. Acute LAP is frequently encountered in clinical practice, and is often associated with acute upper respiratory tract infections. It has a duration of less than four weeks and shows spontaneous regression, although some may persist longer. LAP persisting longer than four weeks is defined as chronic lymphadenopathy and is associated with malignancies or certain infectious diseases (1-3). Cervical lymph nodes measuring less than $1 \mathrm{~cm}$ have been associated with a benign etiology, cervical lymph nodes measuring 1-3 cm have been associated with benign or malignant etiologies, and cervical lymph nodes measuring more than $3 \mathrm{~cm}$ have been associated with a malignant etiology $(4,5)$. In general, a lymphadenopathy measuring more than $2 \mathrm{~cm}$ are associated with malignancies and granulomatous diseases and need to be clarified $(6,7)$.

The differentiation of malignant from benign causes is critically important, and so increasing the armamentarium of additional predictive factors and findings that would alert the clinician would be beneficial in the clinical follow-up of pediatric patients with cervical LAP. In the literature, there have been studies demonstrating the vital prognostic significance of the neutrophil-lymphocyte ratio (NLR) in lymphoid system cancers such as Hodgkin lymphome $(8,9)$, diffuse B-cell lymphome $(10,11)$ and follicular lymphoma (12). These results suggests that an increase in NLR could be related to tumor growth in lymphadenopathy.

However, to best of our knowledge, no other study evaluating the relationship between pediatric cervical lymphadenopathy and NLR was encountered. Thus, in the present study we aimed to evaluate whether or not the NLR in a complete blood count can be used as an auxiliary parameter by clinicians in the assessment of children with cervical lymphadenopathy.

\section{MATERIALS and METHODS}

The study was approved by Clinical Research Ethics Committee of our institution (Approval Number: 2018.3.20). The research was designed as a retrospective clinical study involving patients under the age of 18 who were evaluated at our hospital between 1991 and 2017. There are three groups and 86 patients in the study. The first group was assigned as the control group (group 1), comprising 30 patients who underwent circumcision or inguinal hernia repair in our hospital. The second group was composed of 30 patients who were examined in the otorhinolaryngology and/or pediatric hematology-oncology outpatient clinics due to one or more enlarged cervical lymph nodes, persisting for at least four weeks, measuring ultrasonographically $2 \mathrm{~cm}$ or above, and who had no sign of an active infection and any finding in the follow-up was regarded as suspicious for malignancy (group 2-study group). The second group consisted of patients with no malignancy for at least nine months and no excisional surgery for LAP. The third group (group 3) was composed of 26 patients who presented to the pediatric hematologyoncology outpatient clinics with cervical lymphadenopathy and who were diagnosed with Hodgkin lymphoma following an excisional biopsy.

Patients with a systemic, chronic and autoimmune disease in the first and second group were excluded from the study. Also in the second group, patients with findings of an active infection or abnormal leukocyte and/or platelet count and/or anemia in the laboratory tests, elevated CRP or erythrocyte sedimentation rate, and patients with a mass lesion, reported on ultrasonography (USG), other than LAP were excluded. Patients in the third group who were diagnosed with a disease other than stage 1 and 2 Hodgkin lymphoma were excluded from the study. 
The absolute neutrophil and lymphocyte counts that were obtained from the complete blood count prior to the operation in the first group, during follow-up visits in the second group, and before beginning oncological therapy in the third group were reviewed retrospectively. The NLR in the groups were analyzed through statistical methods.

The statistical analyses were performed with IBM SPSS Statistics for Windows, Version 22.0. Armonk, NY: IBM Corp. Normality of distribution was checked initially with a Shapiro-Wilk test and the test showed non-normal distribution that a MannWhitney U-test and Kruskal-Wallis test were used to compare the parameters. Pearson ChiSquare test were used to compare the parameters for sex. A $\mathrm{P}$ value of $<0.05$ was considered statistically significant. A receiver operating characteristic (ROC) curve analysis was performed to determine the sensitivity and specificity rate of NLR.

\section{RESULTS}

There were 30 (F/M: 12/18), 30 (F/M: 7/23) and 26 (F/M: 6/20) subjects in Groups 1, 2 and 3 , respectively. The median age was 6 years (min: 3-max: 14) in Group 1, 7 years (min: 3max: 16) in Group 2 and 8.5 years (min: 1min: 17) in Group 3. There was no statistically significant difference between the groups in terms of age and sex (p>0.05) (Table 1)

The median NLR was 1.05 (min: 0.44max: 6.31) in Group 1, 1.36 (min: 0.54- max: 8.40) in Group 2 and 1.79 (min: 0.54-max: 9.63) in Group 3 (Table 1). There was a statistically significant difference between the mean NLRs of the three groups $(\mathrm{P}=0.005 ; \mathrm{p}$ $<0.05)$, and a particularly significant difference between the mean NLRs of Group 1 and $3(\mathrm{P}=$ $0.003 ; \mathrm{p}<0.05)$, between Group 2 and Group 3 $(\mathrm{P}=0.026 ; \mathrm{p}<0.05)$. The difference between Group 1 and Group $2(\mathrm{P}=0.147 ; \mathrm{p}>0.05)$ was comparable (Table 2 and Figure 1).

When ROC analysis was performed based on the NLR value of 1.2 corresponded to the maximum combined sensitivity and specificity on the ROC curve, $40 \%$ sensitivity and $33 \%$ specificity was determined. The area under the curve was 0.66 (Figure 2).

\section{DISCUSSION}

Previous studies in literature emphasize that LAPs persisting longer than four weeks and that are highly suspicious for malignancy should be examined carefully, with lymph node excision and histopathological examination recommended in such patients (13). Patients with lymphadenopathy persisting for more than four weeks despite medical therapy, and showing a benign character on ultrasonography that is not clinically suspicious for malignancy, have been encountered in our clinic, and some of these patients have been handled together with the pediatric hematology and oncology departments. In order to avoid unnecessary biopsy procedures in these patients, it is important to establish clinically significant risk factors and increase the armamentarium of parameters that would aid clinicians.

In clinical practice, ultrasonographic examination and laboratory tests are ordered in children presenting with a cervical LAP (13). In a literature reviews of laboratory examinations, Oguz et al. identified a relationship between malignancy and elevated lactate dehydrogenase (LDH), erythrocyte sedimentation rate (ESR), C-reactive protein (CRP) and uric acid levels (1), and Matsumoto et al. found higher LDH levels and upregulated interleukin-2 receptors in patients with malignant LAP (14). In their study, Bozlak et al. evaluated leukocyte, platelet, hemoglobin, CRP, ESR, LDH and serum uric acid levels in patients with benign and malignant LAP, and thrombocytopenia was significantly higher among the patients found to have malignancy. Furthermore, CRP and LDH levels were significantly higher in patients with malignancy. Uric acid levels were similar across all groups, and there was no difference in terms of total WBC count.

In the literature, the association between NLR and oncogenesis has been investigated in many studies $(8-11,15)$. NLR had been shown as a predictive value for survive in malignancies including mesothelioma, rectal, gastric and colon cancer (15). Also, in squamous cell carcinoma of the vulva, NLR was found significantly higher in the lymph-node positive group than in the negative group (16). However, to best of our knowledge, no other study evaluating the 
relationship between pediatric cervical lymphadenopathy and NLR was encountered. Thus, the present study compared the NLR of patients with a chronic LAP measuring above $2 \mathrm{~cm}$ on ultrasonographic examination, and with no physical examination findings or ultrasonographic characteristics suggestive of malignancy, with the control group and patients with Hodgkin lymphoma, which is the most common form of cancer in childhood, originating from the lymphoid system. We found that patients with Hodgkin lymphoma had significantly higher NLR when compared to those in the control group and patients with chronic LAP. A comparison of the patients with chronic LAP and the control group showed no significant difference in terms of NLR. It was advocated that an elevated neutrophil count could promote tumor growth and metastasis and/or inhibit lymphocyte activity, and thereby disrupt antitumor immune response, and it has been further mentioned that disruption in the NLR could be related with tumor growth (8). In the present study there was a significant disruption in the balance of the neutrophil and lymphocyte counts in the malign group.

However, when we performed ROC analysis according to the NLR value of 1.2 corresponded to the maximum joint sensitivity and specificity, we received low specificity and sensitivity ratios, respectively $33 \%$ and $40 \%$. In addition, the analysis was performed to distinguish malign patients from benign and healthy controls according to mean NLR value (2.4) of the group with lymphoma and we found sensitivity $13 \%$ and specificity $83 \%$. These results suggest us that NLR cannot be used as an effective and reliable tool to detect malignancy.

Previously, a relationship between systemic inflammatory response in the cancer area and oncogenesis established (15). Inflammation is considered to play an important role in the neoplastic process by activating the proliferation, survival and migration of tumor cells $(17,18)$. In Haddad et al. study evaluated the relationship between NLR and disease prognosis and survival in patients with squamous cell carcinoma of the head and neck. In Haddad et al study, the mean NLR of 46 patients was 3.3, while the metastasis-free and locoregional relapse-free survival rate were significantly higher among patients with NLR higher than 5.5 before the initiation of therapy (17). There have also been recent studies evaluating the effect of NLR on the survival of patients with Hodgkin lymphoma and diffuse B-cell lymphoma (811, .). In the study by Porrata et al., an NLR below 3.5 was found to contribute favorably to survival in patients with diffuse B-cell lymphoma (11). In a retrospective study of 342 adult patients with classical Hodgkin lymphoma reported by Koh et al., a high NLR $(>4.3)$ was correlated with poor overall survival (8). The mean NLR in the present study was 2.4 in the malignancy group, compared to 1.4 and 1.6 in the control group and in patients with chronic LAP, respectively. Unlike in other studies, the present study was conducted with pediatric patients, thus NLR may be found in the malignancy group was lower than those reported in adult patients. In accordance with our work, the studies investigate the prognostic value of NLR in pediatric populations with solid tumors and sarcomas, the cut-off value of 2.5 and 2 respectively for NLRs were accepted $(19,20)$.

The present study had some limitations. The small number of patients in the groups was the first. Secondly, in this study we included the patients with LAP at least four weeks without excisional biopsy, however there were patients followed by both otolaryngology and pediatric hematology who had more than six months of LAP without no suspicion of malignancy and without excisional biopsy. NLR values of benign and malignant patients with excisional biopsy may be the subject of another study.

\section{CONCLUSION}

The results obtained in the present study reveal a relationship between malignancy in patients with cervical lymphadenopathy and increased NLR. Thus, NLR may be thought to be used as a predictive parameter in the evaluation of pediatric patients with cervical lymphadenopathy. However, unsatisfactory values in terms of specificity and sensitivity analysis restricts the use of a reliable parameter to detect malignancy.

Informed Consent: No formal consent is required for this type of study. 
Conflict of Interest: The authors declare no conflict of interest.
Financial Disclosure or Funding: The authors declare that this study was carried out with no financial support or funding.

Table 1: Descriptive statistics for age, sex and neutrophil-to- lymphocyte ratio

\begin{tabular}{lllll}
\hline & Group 1 (n=30) & Group 2 (n=30) & Group 3 (n=26) & $\boldsymbol{P}$ \\
\hline $\begin{array}{l}\text { Age (years) } \\
\text { Median (minimum-maximum) }\end{array}$ & $6(3-14)$ & $7(3-16)$ & $8.5(1-17)$ & $\mathbf{0 . 2 1 3}$ \\
Sex & & & & \\
Female & $12(40 \%)$ & $7(23.3 \%)$ & $6(23.1 \%)$ & $\mathbf{0 . 2 6 3}$ \\
Male & $18(60 \%)$ & $23(76.7 \%)$ & $20(76.9 \%)$ & \\
NLR & & & & \\
Median & & & \\
Minimum-maximum & 1.05 & 1.36 & 0.005 \\
Interquartile Range & $0.44-6.31$ & $0.54-8.40$ & $0.54-9.63$ & \\
& 0.93 & 0.55 & 1.97 &
\end{tabular}

Group 1, control group; Group 2, patients with chronic lymphadenopathy; Group 3, patients with Hodgkin lymphoma; NLR, neutrophil-to-lymphocyte ratio.

$p$ values based on Kruskal-Wallis test for age and NLR, Pearson Chi-Square test for sex

Table 2: Comparison of median NLR values of groups

\begin{tabular}{lllll}
\hline & Group 1 & Group 2 & Group 3 & P value \\
\hline NLR & 1.05 & 1.36 & 1.79 & $\mathbf{0 . 0 0 5 \boldsymbol { F }}$ \\
NLR & 1.05 & 1.36 & & $\mathbf{0 . 1 4 7}^{*}$ \\
NLR & 1.05 & & 1.79 & $\mathbf{0 . 0 0 3 *}$ \\
NLR & & 1.36 & 1.79 & $\mathbf{0 . 0 2 6 ^ { * }}$ \\
\hline
\end{tabular}

f Kruskal-Wallis test *Mann-Whitney U test 


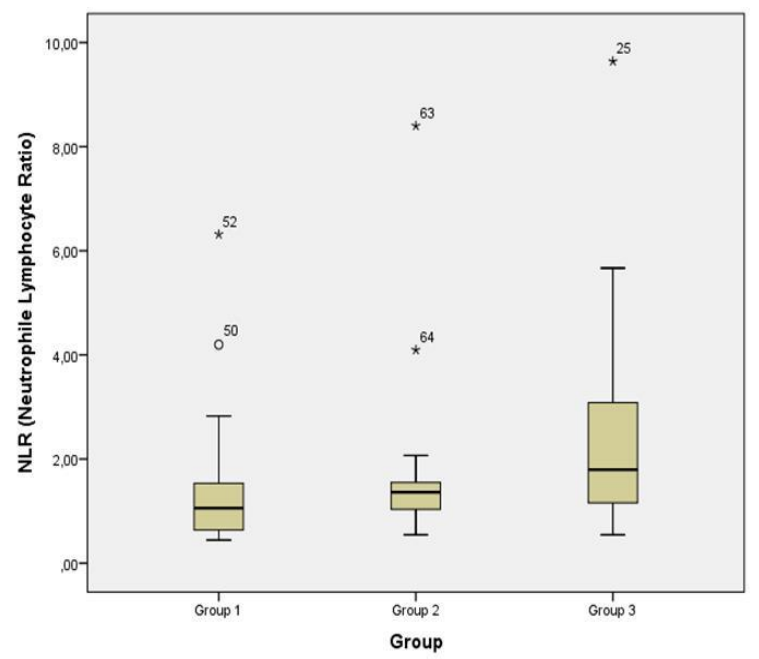

Figure 1: NLR values of three groups

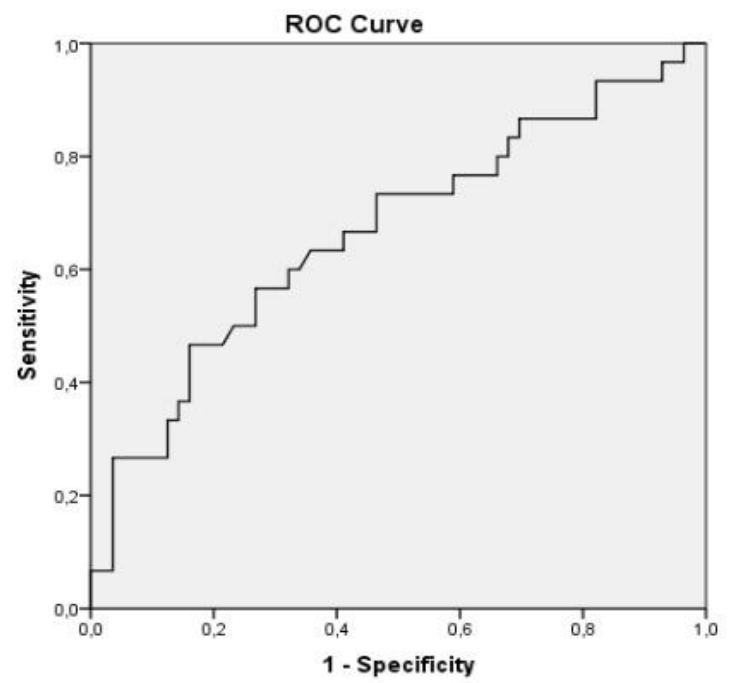

Figure 2: ROC curve of NLR. The area under curve is 0.66 .

\section{REFERENCES}

1. Oguz A, Karadeniz C, Temel EA, Citak EC, Okur FV. Evaluation of peripheral lymphadenopathy in children. Pediatric Hematology and Oncology 2006; 23: 549-561.

2. Bozlak S, Varkal MA, Yıldız I, Toprak S, Karaman $\mathrm{S}$, Erol OB, et al. Cervical lymphadenopathy in children : A prospective clinical cohort study. Int. J. Pediatr. Otorhinolaryngol. 2016; 82: 81-87.

3. Citak EC, Koku N, Demirci M, Tanyeri B, Deniz H. A retrospective chart review of evaluation of the cervical lymphadenopathies in children. Auris Nasus Larynx 2011; 38: 618-621.

4. Kinght PJ, Mulne AF, Vassy LE. When is lymp node biopsy indicated in children with enlarged peripheral nodes? Pediatrics 1982; 69: 391-396.

5. Karadeniz C, Oğuz A, Ezer U, Ozturk G, Dursun A. The etiology of peripheral lymhadenopathy in children. Pediatric Hematology Oncology 1999; 16: 525-531.

6. SlapGB, Brook JS, Schwartz JS. When to perform biopsies of enlarged peripheral lymph nodes in young patients. JAMA 1984; 252: 1321-1326.

7. Moore SW, Schneider JW, Schaaf HS. Diagnostic aspects of cervical lymphadenopathy in children incidence and diagnostic management. Int. J. Pediatr. Otorhinolaryngol. 2007; 71: 51-56.

8. Koh YW, Kang HJ, Park C, Yoon DH, Kim S, Suh C, et al. Prognostic Significance of the Ratio of Absolute Neutrophil Count to Absolute Lymphocyte Count in Classic Hodgkin Lymphoma. Am J CLin Pathol 2012; 138: 846-854.

9. Marcheselli R, Bari A, Tadmor T, Marcheselli L, Cox C, Pozzi S, et al. Neutrophil-lymphocycte ratio at diagnosis is an independent prognostic factor in patients with nodular sclerosis Hodgkin lymphoma: results of a large multicenter study involving 990 patients. Hematological Oncology 2017;35: 561566

10. Troppan K, Deutsch A, Gerger A, Stojakovic T, Beham-Schmid C, Wenzl K, et al. The derived neutrophil to lymphocyte ratio is an independent prognostic factor in patients with diffuse large Bcell lymphoma. Br J cancer. 2014; 110: 369-374.

11. Porrata LF, Ristow $K$, Habermann $T$, Inwards DJ, Micallef IN, Markovic SN. Predicting survival for difusse large B-cell lymphoma patients using baseline neutrophil/lymphocyte ratio. Am $J$ Hematol.2010; 85: 896-899.

12. Lee SF, Luque-Fernandez MA. Prognostic value of lymphocyte-to-monocyte ratio and neutrophil-tolymphocyte ratio in follicular lymphoma:a retropsective cohort study. BMJ Open 2017, doi: 10.1136/bmjopen-2017-017904.

13. Çelenk F, Baysal E, Aytaç I, Durucu C, Sarı I, Mumbuc S, Kanlikama M. Incidence and predictors of malignancy in children with persistent cervical lymphadenopathy. Int. J. Pediatr. Otorhinolaryngol. 2013; 77: 2004-2007.

14. Matsumoto F, Itoh $S$, Ohba $S$, Yokoi H, Furukawa M, Ikeda K. Biopsy of cervical lymph node. Auris Nauris Larynx 2009; 36: 71-74.

15. Haddad CR, Guo 1, Clarke S, Guminski A, Back M, Eade T. Neutrophil-to -lymphocyte ratio in head and neck cancer. Journal of Medical Imaging and Radiation Oncology 2015; 59: 514-519.

16. Ertaş IE, Güngördük $K$, Akman L, Özdemir A, Terek MC, Ozsaran A, Sancı M, Dikmen Y. Can preoperative neutrophil:lymphocyte and platelet:lymphocyte ratios be used as predictive markers for lymph node metastasis in squamous cell carcinoma of the vulva? Eur J Obstet Gynecol Reprod Biol. 2013;171:138-42.

17. Quail DF, Joyce JA. Microenvironmental regulation of tumor progression and metastasis. Nat. Med. 2013;19: 1423-1437. 
18. Coussens LM, Werb Z. Inflammation and cancer. Nature 2002; 420: 860-867.

19. Nayak A, McDowell DT, Kellie SJ, Karpelowsky J. Elevated Preoperative NeutrophilLymphocyte Ratio is Predictive of a Poorer Prognosis for Pediatric Patients with Solid Tumors. Ann Surg Oncol. 2017; 24: 3456-3462.
20. Vasquez L, León E, Beltran B, Maza I, Oscanoa M, Geronimo J. Pretreatment Neutrophil-toLymphocyte Ratio and Lymphocyte Recovery: Independent Prognostic Factors for Survival in Pediatric Sarcomas. J Pediatr Hematol Oncol. 2017;39: 538-546. 